P-ISSN 2580 - 7781

E-ISSN 2615 - 3238

\title{
UJI ADAPTASI VARIETAS UNGGUL BARU PADI SAWAH BERBASIS PENERAPAN TEKNOLOGI TERPADU DI KECAMATAN KARANGSAMBUNG KABUPATEN KEBUMEN
}

\section{TEST ADAPTATION OF NEW SUPERIOR VARIETIES OF RICE FIELDS BASED ON THE APPLICATION OF INTEGRATED TECHNOLOGY IN KARANGSAMBUNG KEBUMEN}

\author{
Umi Barokah ${ }^{1)}$, Rahmat Joko Nugroho ${ }^{2)}$, Miftahul Huda ${ }^{3)}$ \\ ${ }^{1,2}$ Dosen Agroteknologi Fakultas Pertanian dan Peternakan Universitas Ma'arif Nahdlatul \\ Ulama Kebumen \\ ${ }^{3}$ Mahasiswa Agroteknologi Fakultas Pertanian dan Peternakan Universitas Ma'arif \\ Nahdlatul Ulama Kebumen \\ ${ }^{1}$ Email : barokahumi@yahoo.com
}

\begin{abstract}
ABSTRAK
Kebutuhan beras meningkat seiring dengan meningkatnya jumlah penduduk tiap tahunnya. Konsumsi beras di Indonesia sebesar 114,6/kapita/tahun pada tahun 2017 dengan jumlah penduduk Indonesia 265 juta jiwa dengan produksi padi nasional mencapai 81,149 juta ton dengan luas panen 15,712 juta $\mathrm{Ha}$ dan produktivitas padi mencapai 51.65 juta ton. Dengan kondisi ketergantungan pangan pada satu jenis produk dapat menjadikan Indonesia rawan pangan. Oleh sebab itu diperlukan pengembangan varietas unggul baru padi yang mampu berproduksi tinggi agar mampu mencukupi kebutuhan pangan Indonesia yang tinggi. Penelitian telah dilaksanakan di Desa Seling, Kecamatan Karangsambung, Kabupaten Kebumen pada bulan Mei hingga Agustus 2020. Sebanyak sepuluh varietas unggul baru padi sawah dan dua varietas pembanding favorit petani yaitu Ciherang dan IR64 diuji dalam penelitian ini. Penanaman dilakukan secara pindah tanam dengan menggunakan bibit berumur 17 Hari Setelah Sebar (HSS) sebanyak 1bibit/lubang tanam dengan sistem tanam jajar legowo 2:1 dengan jarak tanam $25 \mathrm{~cm} \mathrm{x}$ $12.5 \mathrm{~cm}$ x $50 \mathrm{~cm}$ pada plot berukuran $4 \mathrm{~m}$ x $5 \mathrm{~m}$. Penelitian ditata dengan menggunakan Rancangan Acak Kelompok Lengkap dengan empat ulangan. Teknik budidaya dilakukan sesuai petunjuk penerapan teknologi terpadu. Pengamatan dilakukan terhadap karakter keragaan agronomis dan hasil. Hasil analisis varian menunjukkan terdapat perbedaan antar varietas yang diuji pada karakter hasil, jumlah anakan, umur berbunga 50\%, jumlah gabah hampa per malai dan seed set serta tidak menunjukkan perbedaan yang nyata pada karakter yang lainnya serta varietas Inpari 44 (6.8 ton/ha), Bawor (6.55 ton/ha), Inpari 43 (6.5 ton/ha) dan Inpari 32 (6.15 ton/ha) menunjukkan adaptasi yang lebih tinggi dari varietas pembanding Ciherang (6.1 ton/ha) di Kecamatan karangsambung, Kabupaten Kebumen.
\end{abstract}

Kata kunci: Varietas, Unggul, Baru, Padi.

\begin{abstract}
The need for rice increases as the population increases each year. Rice consumption in Indonesia amounted to 114.6 /capita/year in 2017 with a population of Indonesia of 265 million people with national rice production reaching 81.149 million tons with a harvest area of 15,712 million $\mathrm{Ha}$ and rice productivity reaching 51.65 million tons. With food dependency conditions on one type of products can make Indonesia food prone. Therefore, it is necessary to develop new superior varieties of rice that are capable of high production in order to be able to meet Indonesia's high food needs. The research has
\end{abstract}


P-ISSN 2580 - 7781

E-ISSN 2615 - 3238

been conducted in Seling, Karangsambung, Kebumen in May to August 2020. A total of ten new superior varieties of rice paddy and two varieties of farmers' favorite comparisons, Ciherang and IR64 were tested in this study. Planting is done by moving planting using seedlings aged 17 days after scatter (HSS) as much as one seed / hole planting with a 2:1 jajar legowo planting system with a planting distance of $25 \mathrm{~cm} \times 12.5$ $\mathrm{cm} \times 50 \mathrm{~cm}$ on a plot measuring $4 \mathrm{~m} \times 5 \mathrm{~m}$. The research was organized using a Complete Group Randomized Design with four replays. Cultivation techniques are carried out in accordance with the instructions for the application of integrated technology. Observations were made on the character of agronomic apes and results. Variant analysis shows there are differences between varieties tested on the character of the result, the number of puppies, the age of flowering 50\%, amount of hollow grain per malai and seed set and shows no noticeable difference in other characters as well as inpari varieties 44 (6.8 tons/ha), Bawor (6.55 tons/ha), Inpari 43 (6 .5 tons/ha) and Inpari 32 (6.15 tons/ha) showed higher adaptation of Ciherang comparative varieties (6.1 tons/ha) in Karangsambung, Kebumen.

Keywords: Variety, Superior, New, Rice.

\section{PENDAHULUAN}

Beras merupakan makanan pokok bagi sebagian besar masyarakat Indonesia. Konsumsi beras di Indonesia semakin meningkat setiap tahunnya seiiring dengan meningkatnya jumlah penduduk Indonesia. Pada tahun 2017 konsumsi beras di Indonesia sebesar 114,6/kapita/tahun dengan jumlah penduduk Indonesia 265 juta jiwa dengan produksi padi nasional mencapai 81,149 juta ton dengan luas panen 15,712 juta Ha dan produktivitas padi mencapai 51.65 juta ton (BPS, 2017). Dengan kondisi ketergantungan pangan pada satu jenis produk dapat menjadikan Indonesia rawan pangan. Oleh sebab itu diperlukan pengembangan varietas unggul baru padi yang mampu berproduksi tinggi agar mampu mencukupi kebutuhan pangan Indonesia yang tinggi. Kabupaten Kebumen merupakan salah satu kabupaten di Provinsi Jawa Tengah yang sebagian besar wilayahnya merupakan daerah pertanian khususnya padi. Luas panen pada tahun 2017 mencapai 73.924,10 Ha dengan produksi 411.387,62 ton sedangkan luas panen untuk Kecamatan Karangsambung 3.069,50 Ha dengan produksi 17.081,77 ton (BPS Kab.Kebumen, 2017). Dengan demikian berarti hasil rata-rata produksi padi di Kecamatan Karangsambung 5,56 ton/Ha. Ini dikatakan masih rendah dari target pemerintah yang menargetkan produksi padi 8-9 ton/Ha. Hal ini dikarenakan petani daerah tersebut masih mengandalkan menanam padi favorit mereka yaitu Ciherang dan IR64 belum menanam padi varietas unggul baru yang hasil produksinya tinggi. 
P-ISSN 2580 - 7781

E-ISSN 2615 - 3238

Ciherang dan IR64 seiring berkembangnya waktu sudah tidak tahan terhadap hama dan penyakit tanaman padi. Hal ini dikarenakan penanaman varietas yang secara terus menerus menyebabkan ketahanan terhadap hama penyakit menjadi menurun. Berdasarkan pengamatan di lapangan, Ciherang kurang tahan terhadap penyakit hawar daun bakteri atau yang sering disebut penyakit kresek. Penyakit hawar daun bakteri disebabkan oleh bakteri Xanthomonas oryzae pv. oryzae (Xoo) (Kadir et al., 2009). Kisaran suhu dan kelembaban yang tinggi mendukung perkembangan penyakit hawar daun bakteri pada saat tanaman memasuki stadia vegetatif akhir 40-50 hari setelah tanam (Lestari et al., 2007). Pengendaliaan hawar daun bakteri yang paling efektif dan ekonomis adalah menggunakan varietas tahan. Serangan hawar daun bakteri di Indonesia pada tahun 2012 mencapai 81.119 hektar (Direktorat Perlindungan Tanaman Pangan, 2012). Penyakit hawar daun bakteri jika menyerang tanaman padi berdasarkan penelitian dapat menurunkan produksi padi sehingga hasil panenan padi tidak akan dapat optimal. Sama halnya dengan varietas IR64, berdasarkan pengamatan di lapangan varietas ini sudah kurang tahan terhadap serangan hama wereng. Jika hama wereng sudah menyerang tanaman dan tidak bisa dikendalikan maka produksi padi tersebut akan turun bahkan bisa menyebabkan gagal panen. sebagaimana pada tahun 1986, wereng menyerang daerah Jawa Tengah meliputi areal \pm 75.000 ha (Rugaya dan Dahyar, 2013). Pada periode tahun 2000-2005, luas areal pertanaman padi yang terserang hama wereng batang cokelat mencapai 20.000 ha per tahun (Kartohardjono, 2011). Serangan hama wereng batang cokelat mencapai 23.187 ha sampai bulan Juni 2010 (Balai penelitian tanaman padi, 2011). Serangan hebat tersebut dikarenakan kemampuan hama wereng ini dalam beradaptasi dan dapat membentuk biotipe baru dengan sangat cepat serta mampu menularkan virus kerdil rumput dan virus kerdil hampa yang dapat menyebabkan kerusakan tanaman padi menjadi lebih parah (Effendi, 2009).

Kendala lain di Kecamatan Karangsambung yaitu kurang berkembangnya informasi tentang varietas unggul baru padi yang produksinya lebih tinggi dan tahan terhadap organisme pengganggu tanaman ke petani sehingga petani masih 
P-ISSN 2580 - 7781

E-ISSN 2615 - 3238

selalu menanam Ciherang dan IR64. Atas permasalahan tersebut, maka perlu solusi agar hasil produksi padi petani di Kecamatan Karangsambung dapat meningkat, yaitu dengan pengenalan varietas unggul baru padi dengan uji adaptasi varietas unggul baru padi. Varietas-varietas unggul baru padi yang produksinya tinggi dan tahan terhadap organisme pengganggu tanaman akan ditanam di lahan percobaan petani, agar petani dapat mengenal dan memilih varietas unggul baru padi yang mereka sukai dengan indikator hasilnya tinggi dan tahan terhadap hama penyakit. Diharapkan dari kegiatan ini akan diperoleh varietas unggul baru padi yang berdaya hasil tinggi dan tahan hama penyakit dan mampu menambah referensi petani tentang daftar nama varietas padi menjadi lebih banyak dan dapat membudidayakannya agar produksi padi petani menjadi lebih tinggi dibanding jika menanam dengan varietas Ciherang dan IR64.

\section{BAHAN DAN METODE}

Penelitian telah dilaksanakan pada bulan Mei sampai Agustus tahun 2020 di desa Seling, Kecamatan Karangsambung, Kabupaten Kebumen. Lahan yang digunakan merupakan sawah irigasi teknis. Materi yang diuji cobakan ditanam di lahan percobaan dengan membandingkan 10 varietas unggul baru padi dengan 2 varietas yang umum ditanam oleh petani setempat yaitu Ciherang dan IR64 dengan menggunakan pendekatan penerapan teknologi terpadu (PTT). Sepuluh varietas baru padi yang digunakan adalah Inpari 30, Bawor, Inpari 32, Inpari 33, Inpari 42, Inpari 43, Inpari 44, Siliwangi, Padjajaran, Cakrabuana. Rancangan penelitian yang digunakan adalah Rancangan Acak Kelompok (RAK) dengan faktor tunggal yaitu varietas unggul baru padi. Masing-masing varietas tanaman ditanam dengan system tanam legowo 2:1 (jarak tanam 25 x 12,5 x $50 \mathrm{~cm}$ ) dengan luas plot $4 \mathrm{~m}$ x 5m dengan empat kali ulangan. PTT digunakan dalam penelitian ini, yaitu benih menggunakan benih berlabel, pengolahan tanah dilakukan secara sempurna, umur bibit muda yaitu 17 Hari Setelah Semai (HSS) dan penggunaan pupuk sesuai dosis yaitu pupuk NPK Phonska $250 \mathrm{~kg} / \mathrm{ha}$ dan Urea $200 \mathrm{~kg} / \mathrm{ha}$ dengan frekuensi pemupukan sebanyak 3 kali yaitu pemupukan I = 7 Hari Setelah Tanam (HST), II = 22 HST dan III = 35 HST. Pengendalian gulma dan pengendalian hama dan penyakit dilakukan dengan menggunakan prinsip 
P-ISSN 2580 - 7781

E-ISSN 2615 - 3238

Pengendalian Hama Terpadu (PHT). Pengamatan dilakukan terhadap karakter keragaan agronomis tanaman seperti tinggi tanaman, jumlah anakan, umur berbunga, jumlah malai, jumlah gabah isi per malai, jumlah gabah hampa per malai, berat gabah isi per rumpun, seed set (fertilitas), bobot 1000 butir dan hasil (gabah kering panen). Data hasil pengamatan diinput kemudian dianalisis dengan menggunakan software statistic SAS dan beda rata-rata antar varietas diuji menggunakan metode uji LSD pada ambang taraf kesalahan sebesar 5\%.

\section{HASIL DAN PEMBAHASAN}

Secara umum pelaksanaan percobaan di lapangan berjalan lancar. Namun demikian terjadi serangan hama burung pada varietas Padjajaran dan Cakrabuana pada saat tanaman memasuki fase berbunga yaitu sekitar umur 60 HSS. Hal ini dikarenakan varietas tersebut memiliki umur berbunga yang sangat genjah sehingga serangan burung tidak dapat dielakkan lagi. Upaya pengendalian hama burung dilakukan di lapangan dengan cara memasang alat pengusir burung dan juga dijaga oleh petani agar serangan tidak menjadi parah. Efek dari umur berbunga yang genjah ini memunculkan hama belalang datang menyerang dua varietas ini sehingga pengendalian dengan pestisida dilakukan untuk mencegah kehilangan hasil akibat dari hama belalang ini. Selama pelaksanaan penelitian berjalan tidak ditemukan hama wereng menyerang tanaman, namun terjadi gejala serangan penyakit yang menyerang varietas IR64 dimana varietas IR 64 hampir di semua ulangan terserang penyakit hawar daun bakteri dengan presentasi serangan sebesar $75 \%$ sedangkan untuk varietas lain aman dari serangan penyakit ini. Ini membuktikan bahwa varietas unggul baru yang diuji adaptasikan memiliki ketahanan terhadap penyakit hawar daun bakteri.

Hasil analisis varian menunjukkan terdapat perbedaan antar varietas yang diuji pada karakter hasil, jumlah anakan, umur berbunga 50\%, jumlah gabah hampa per malai dan seed set serta tidak menunjukkan perbedaan yang nyata pada karakter yang lainnya (Tabel 1). Keragaan agronomis dan hasil uji adaptasi varietas unggul baru padi sawah berbasis penerapan teknologi terpadu di kecamatan karangsambung, kabupaten Kebumen ditampilkan dalam Tabel 2. 
P-ISSN 2580 - 7781

E-ISSN 2615 - 3238

Tabel 1. Analisis Varians Karakter Agronomis dan Hasil Uji Adaptasi Varietas Unggul Baru Padi Sawah Berbasis Penerapan Teknologi Terpadu Di Kecamatan Karangsambung,

Kabupaten Kebumen

\begin{tabular}{clrr}
\hline No & Variabel Pengamatan & \multicolumn{1}{c}{ Nilai F } & \multicolumn{1}{c}{ Probabilitas } \\
\hline 1 & Hasil & 4.69 & $0.000^{*}$ \\
2 & Tinggi Tanaman & 0.87 & 0.59 \\
3 & Jumlah Anakan & 3.12 & $0.000^{* *}$ \\
4 & Umur Berbunga 50\% & 34.56 & $0.000^{* *}$ \\
5 & Jumlah Malai & 0.99 & 0.48 \\
6 & Gabah Isi/malai & 2.1 & 0.04 \\
7 & Gabah Hampa/malai & 6.49 & $0.000^{* *}$ \\
8 & Berat Gabah Isi/rumpun & 0.89 & 0.58 \\
9 & Seed Set & 4.2 & $0.000^{* *}$ \\
10 & Berat 1000 butir & 18.99 & $0.000^{* *}$ \\
\hline
\end{tabular}

Keterangan : ** = berbeda sangat nyata pada taraf kesalahan $1 \%$

$*$ = berbeda nyata pada taraf kesalahan

Tabel 2. Keragaan agronomis dan hasil uji adaptasi varietas unggul baru padi sawah berbasis penerapan teknologi terpadu di kecamatan karangsambung, kabupaten Kebumen

\begin{tabular}{clrrrrrr}
\hline No & Varietas & UB 50\% & \multicolumn{1}{c}{ JA } & GABHAM & \multicolumn{1}{c}{ SS } & \multicolumn{1}{c}{ B1000 } & \multicolumn{1}{c}{ H } \\
\hline 1 & Inpari 30 & $86 \mathrm{~b}$ & $14 \mathrm{ab}$ & $21 \mathrm{bcd}$ & $84.75 \mathrm{ab}$ & $25.75 \mathrm{~cd}$ & $5.68 \mathrm{bc}$ \\
2 & Bawor & $84 \mathrm{~cd}$ & $15 \mathrm{ab}$ & $20 \mathrm{bcd}$ & $85.75 \mathrm{ab}$ & $28.75 \mathrm{a}$ & $6.55 \mathrm{ab}$ \\
3 & Inpari 32 & $85 \mathrm{bc}$ & $15 \mathrm{ab}$ & $21 \mathrm{bcd}$ & $83.25 \mathrm{ab}$ & $26 \mathrm{bc}$ & $6.15 \mathrm{abc}$ \\
4 & Inpari 33 & $83 \mathrm{de}$ & $15 \mathrm{ab}$ & $15 \mathrm{~d}$ & $87 \mathrm{ab}$ & $27 \mathrm{~b}$ & $5.88 \mathrm{abc}$ \\
5 & Inpari 42 & $86 \mathrm{~b}$ & $13 \mathrm{~b}$ & $25 \mathrm{~b}$ & $85.25 \mathrm{ab}$ & $23.25 \mathrm{f}$ & $5.25 \mathrm{~cd}$ \\
6 & Inpari 43 & $80 \mathrm{f}$ & $17 \mathrm{a}$ & $26 \mathrm{~b}$ & $82.5 \mathrm{~b}$ & $20.75 \mathrm{~g}$ & $6.5 \mathrm{ab}$ \\
7 & Inpari 44 & $91 \mathrm{a}$ & $17 \mathrm{a}$ & $40 \mathrm{a}$ & $74.25 \mathrm{c}$ & $24.25 \mathrm{ef}$ & $6.8 \mathrm{a}$ \\
8 & Siliwangi & $82 \mathrm{e}$ & $17 \mathrm{a}$ & $24 \mathrm{ab}$ & $84 \mathrm{ab}$ & $25.75 \mathrm{~cd}$ & $5.9 \mathrm{abc}$ \\
9 & Padjajaran & $75 \mathrm{~g}$ & $15 \mathrm{ab}$ & $17 \mathrm{~d}$ & $87.25 \mathrm{ab}$ & $24.75 \mathrm{de}$ & $4.05 \mathrm{e}$ \\
10 & Cakrabuana & $76 \mathrm{~g}$ & $15 \mathrm{ab}$ & $16 \mathrm{~d}$ & $87.75 \mathrm{a}$ & $26 \mathrm{bc}$ & $5.15 \mathrm{~cd}$ \\
11 & Ciherang & $85 \mathrm{bc}$ & $16 \mathrm{ab}$ & $18 \mathrm{~cd}$ & $87 \mathrm{ab}$ & $25.25 \mathrm{cde}$ & $6.1 \mathrm{abc}$ \\
12 & IR 64 & $80 \mathrm{f}$ & $16 \mathrm{ab}$ & $19 \mathrm{bcd}$ & $82.5 \mathrm{~b}$ & $24.25 \mathrm{ef}$ & $4.3 \mathrm{de}$ \\
\hline & LSD 5\% & 1.95 & 3.02 & 7.16 & 5 & 1.19 & 1.07 \\
\hline & CV & 1.64 & 13.75 & 22.87 & 4.13 & 3.28 & 13.04 \\
\hline
\end{tabular}

Keterangan: Angka-angka yang diikuti dengan huruf yang sama pada kolom yang sama tidak berbeda nyata pada uji LSD taraf 5\%

$\mathrm{JA}=$ jumlah anakan; UB= umur berbunga $50 \%$ (HSS); GABHAM= jumlah gabah hampa/malai; $\mathrm{SS}=$ seed set $(\%) ; \mathrm{B} 1000=$ bobot 1000 butir $(\mathrm{g}) ; \mathrm{H}=$ hasil $(\mathrm{t} / \mathrm{ha})$

Hasil analisis statistik menunjukkan bahwa terdapat pengaruh nyata macam varietas terhadap keragaan umur berbunga 50\% dari dua belas varietas yang diteliti yang tertera pada Gambar 1 berikut ini. Uji adaptasi varietas unggul baru padi sawah pada karakter umur berbunga 50\% (HSS) (Gambar 1) menunjukkan 
P-ISSN 2580 - 7781

E-ISSN $2615-3238$

bahwa varietas Padjajaran mempunyai umur berbunga paling genjah atau paling cepat dibandingkan dengan varietas yang lainnya yaitu 75 hari setelah sebar. Disusul oleh varietas Cakrabuana yang juga memiliki umur berbunga genjah yaitu 76 hari setelah sebar. Namun demikian berbeda halnya dengan varietas Inpari 44 yang justru menunjukkan umur berbunga 50\% paling dalam atau paling lama jika dibandingkan dengan varietas yang lainnya yaitu 91 hari setelah sebar (Gambar 1). Umur berbunga erat hubungannya dengan umur panen. Varietas yang berbunganya lebih cepat maka umur panennya akan lebih cepat pula. Varietasvarietas yang berumur genjah ini sangat cocok ditanam pada saat musim kemarau yang hubungannya dengan ketersediaan air sehingga tanaman padi cepat dibudidayakan dengan keterbatasan air dan cepat dipanen sehingga tidak terlalu boros dalam penggunaan airnya. Oleh karena itu varietas Padjajaran dan Cakrabuana sangat cocok ditanam pada saat musim kemarau karena umur berbunganya pendek sehingga umur panennya juga pendek sehingga akan lebih cepat dipanen. Terjadinya perbedaan umur berbunga disebabkan oleh perbedaan genetik dari varietas yang dicirikan oleh perbedaan stadia vegetatif dan respon tanaman yang berbeda terhadap tempat tumbuh (Edi S, 2013). Harjadi, S. (1993) mengemukakan bahwa, penampilan suatu varietas akan dipengaruhi oleh 2 faktor yaitu sifat genetik yang dibawanya dan lingkungan tempat dibudidayakan, jika lingkungannya sama maka perbedaan penampilan karakter tanaman akan dipengaruhi oleh sifat genetik tanaman. 


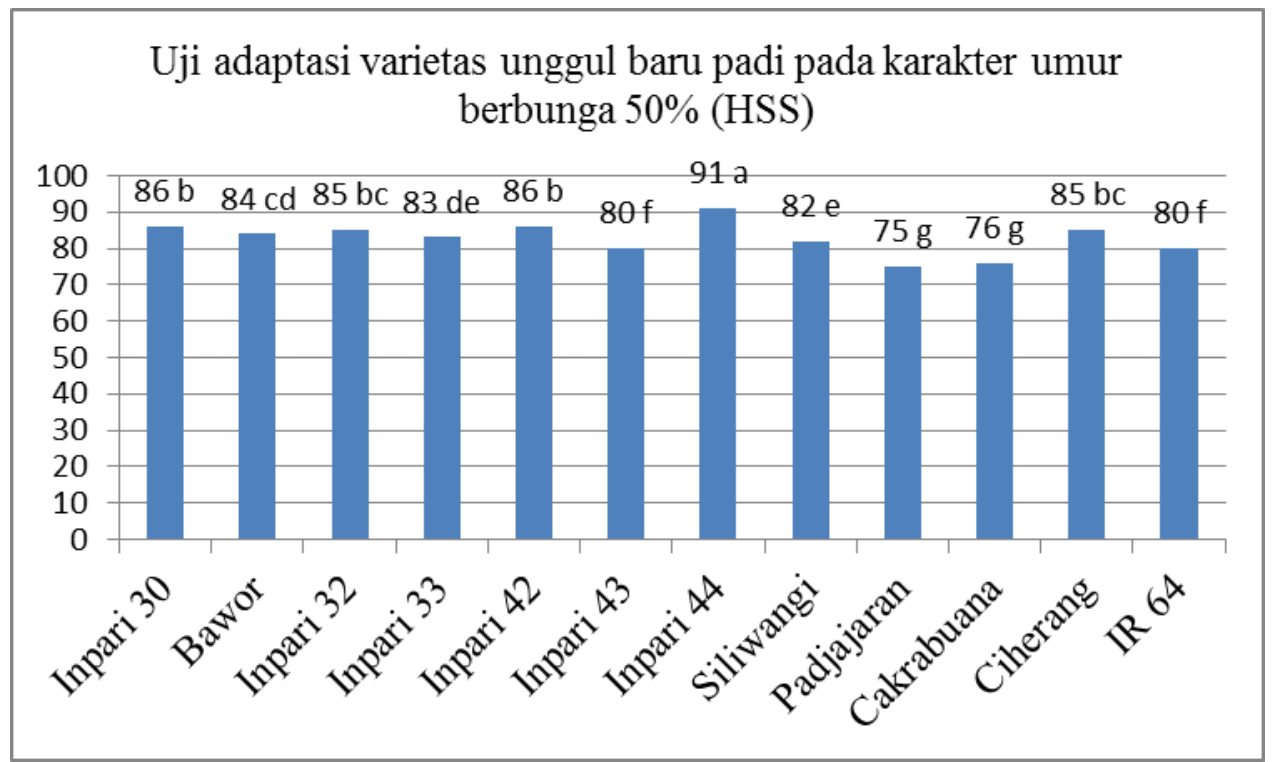

Gambar 1. Uji adaptasi varietas unggul baru padi sawah pada karakter umur berbunga 50\% (HSS)

Hasil analisis statistik menunjukkan bahwa terdapat pengaruh nyata macam varietas terhadap keragaan jumlah anakan dari dua belas varietas yang diteliti yang tertera pada Gambar 2 berikut ini. Semakin tingginya produktivitas tanaman padi ditentukan banyaknya anakan yaitu anakan yang mampu membentuk malai dan mampu mengisi bernas pada malai tersebut (Sutaryo dan Suprihatno, 1994). Uji adaptasi varietas unggul baru padi sawah pada karakter jumlah anakan (Gambar 2) menunjukkan bahwa varietas Inpari 43, Inpari 44 dan Siliwangi memiliki jumlah anakan yang paling tinggi jika dibandingkan dengan varietas yang lainnya yaitu 17 anakan. Berbeda halnya dengan varietas Inpari 42 yang justru mempunyai jumlah anakan paling sedikit dibanding dengan varietas yang lainnya yaitu 13 anakan (Gambar 2). 


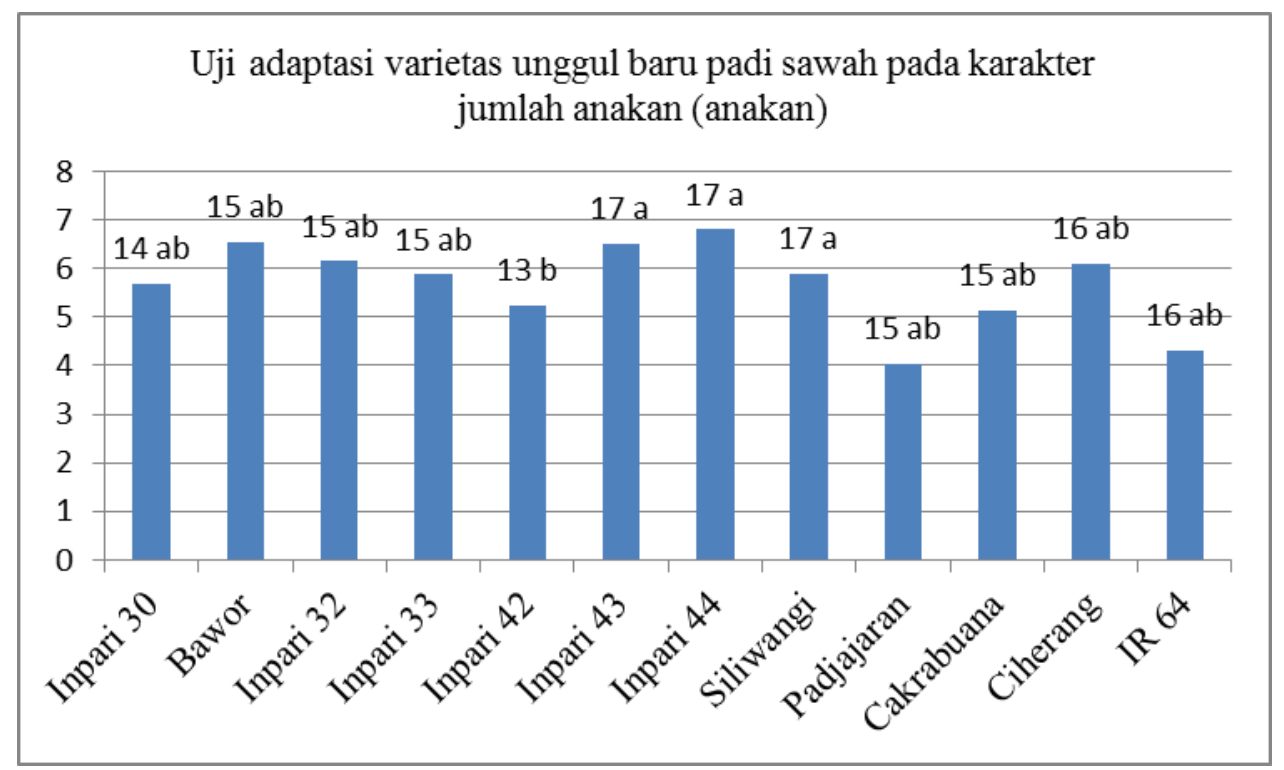

Gambar 2. Uji adaptasi varietas unggul baru padi sawah pada karakter jumlah anakan (Anakan)

Hasil analisis statistik menunjukkan bahwa terdapat pengaruh nyata macam varietas terhadap keragaan jumlah gabah hampa per malai dari dua belas varietas yang diteliti yang tertera pada Gambar 3. Uji adaptasi varietas unggul baru padi sawah pada karakter jumlah gabah hampa per malai pada Gambar 3 menunjukkan bahwa varietas Inpari 33, Cakrabuana dan Padjajaran mempunyai jumlah gabah hampa per malai paling sedikit dibandingkan varietas yang lainnya yaitu 15 butir, 15 butir dan 17 butir. Ini berbanding terbalik dengan varietas Inpari 44 yang justru memiliki jumlah gabah hampa per malai paling banyak diabndingkan varietas yang lainnya yaitu 40 butir (Gambar 3). Perbedaan jumlah gabah per malai yang dihasilkan dari masing-masing varietas disebabkan oleh faktor genetik masingmasing varietas. Hal ini sejalan dengan pendapat Guswara (2007) bahwa jumlah gabah per malai dipengaruhi oleh faktor genetik. Disamping itu faktor lingkungan ikut berperan dalam tinggi rendahnya jumlah gabah permalai, karena keadaan cuaca yang cerah dapat meningkatkan laju fotosintesa, energi cahaya dibutuhkan tanaman untuk proses fotosintesis di mana fotosintat yang dihasilkan akan disimpan dalam jaringan batang dan daun, kemudian akan ditranslokasikan ke gabah tingkat pematangan. Banyak sedikitnya gabah hampa akan mempengaruhi besar kecilnya produktivitas tanaman. Apabila dalam suatu malai terdapat gabah yang sebagian besar hampa maka akan berpengaruh terhadap produktivitas 
P-ISSN 2580 - 7781

E-ISSN 2615 - 3238

tanaman yang semakin rendah dan hasil per hektarnya semakin kecil (Gardner et al, 1991).

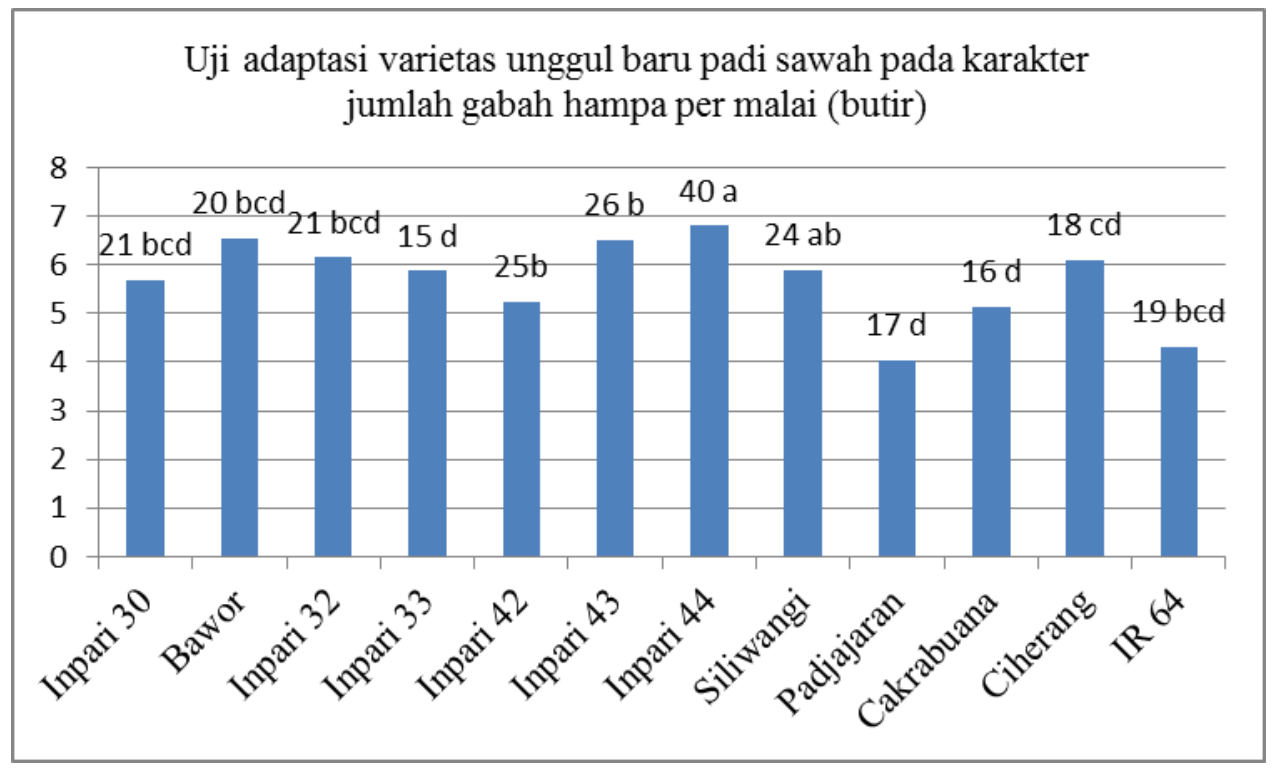

Gambar 3. Uji adaptasi varietas unggul baru padi sawah pada karakter jumlah gabah hampa per malai (Butir)

Hasil analisis statistik menunjukkan bahwa terdapat pengaruh nyata macam varietas terhadap keragaan seed set/fertilitas gabah dari dua belas varietas yang diteliti yang tertera pada Gambar 4. Uji adaptasi varietas unggul baru padi sawah pada karakter seed set/fertilitas gabah pada Gambar 4 menunjukkan bahwa varietas Cakrabuana menunjukkan adaptasi yang paling tinggi yaitu $87.75 \%$ jika dibandingkan dengan adaptasi varietas yang lainnya. Namun demikian, varietas Inpari 30 (84.75\%), Bawor (85.75\%), Inpari 32 ( 83.25\%), Inpari 33 (87\%), Inpari 42 (85.25\%), Siliwangi (84\%), Padjajaran (87.25\%) dan Ciherang (87\%) juga memiliki adaptasi yang baik terhadap karakter seed set/fertilitas gabah walaupun adaptasinya masih di bawah varietas Cakrabuana. Berbeda halnya dengan varietas Inpari 44 yang justru pada karakter seed set/fertilitas gabah menunjukkan adaptasi yang paling rendah yaitu $74.25 \%$ jika dibandingkan dengan adaptasi varietas yang lainnya (Gambar 4). Perbedaan persentase gabah isi ini diduga disebabkan oleh faktor genetik dari tiap varietas tanaman padi yang digunakan. Varietas Cakrabuana relatif lebih stabil dibanding varietas lainnya sehingga memiliki persentase gabah isi yang tinggi. Tingginya persentase gabah isi per malai sangat dipengaruhi oleh jumlah gabah per malai dan jaminan hara yang tersedia. Kondisi 
P-ISSN 2580 - 7781

E-ISSN 2615 - 3238

lingkungan tumbuh yang sesuai cenderung merangsang proses inisiasi malai menjadi sempurna, sehingga peluang terbentuknya bakal gabah menjadi lebih banyak. Namun demikian semakin banyak gabah yang terbentuk, meningkatkan beban tanaman untuk membentuk gabah bernas. Persentase gabah isi merupakan salah satu indikator produktivitas tanaman, semakin tinggi persentase gabah isi yang diperoleh suatu varietas menandakan varietas tersebut mempunyai produktivitas yang tinggi (Mahmud Y. et al, 2014).

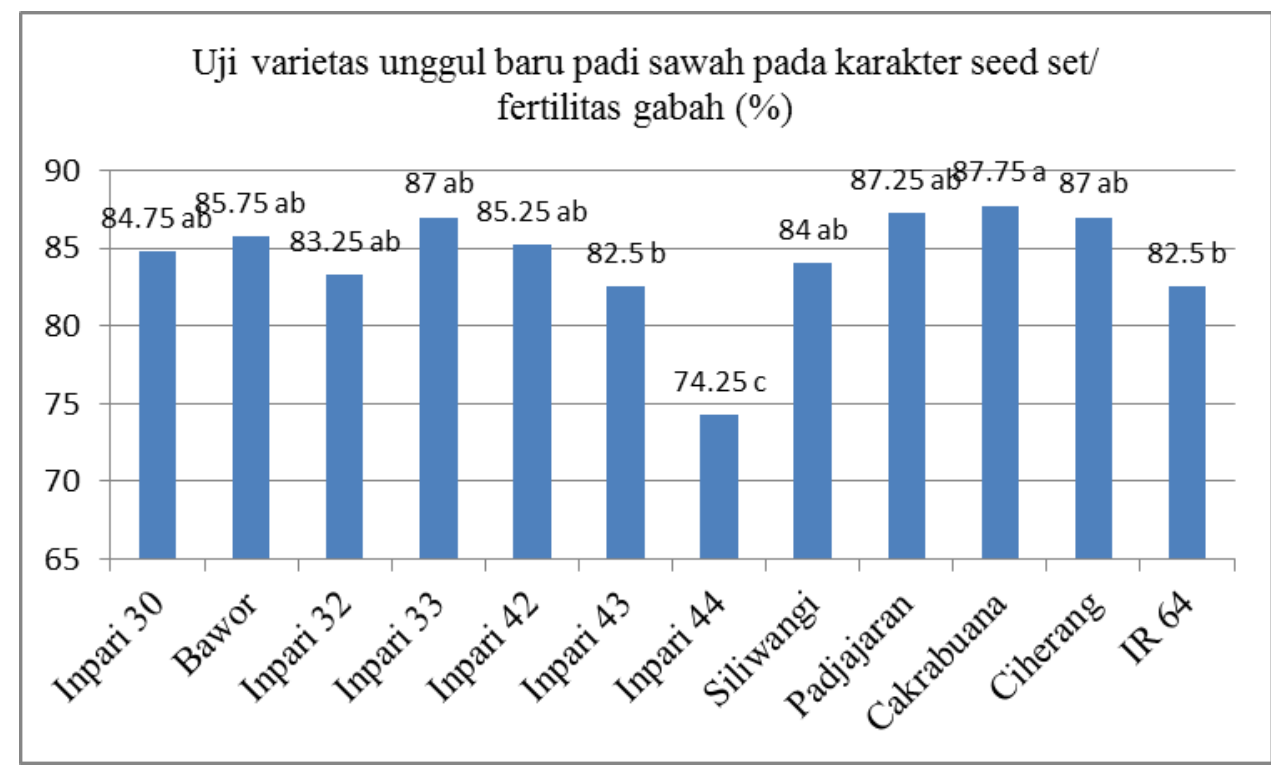

Gambar 4. Uji adaptasi varietas unggul baru padi sawah pada karakter seed set/fertilitas gabah (\%)

Hasil analisis statistik menunjukkan bahwa terdapat pengaruh nyata macam varietas terhadap keragaan bobot gabah 1000 butir dari dua belas varietas yang diteliti yang tertera pada Gambar 5. Uji adaptasi varietas unggul baru padi sawah pada karakter bobot 1000 butir menunjukkan bahwa varietas Bawor memiliki adaptasi paling tinggi yaitu 28.75 gram pada karakter bobot 1000 butir jika dibandingkan dengan adaptasi pada varietas yang lainnya (Gambar 5). Berbeda halnya dengan varietas Inpari 43 yang justru pada karakter bobot 1000 butir menunjukkan adaptasi yang paling rendah yaitu 20.75 gram dibandingkan dengan adaptasi varietas yang lainnya. Perbedaan bobot 1000 butir gabah isi antara hasil percobaan dan deskripsi membuktikan bahwa walaupun secara genotifik varietas- 
P-ISSN 2580 - 7781

E-ISSN 2615 - 3238

varietas tersebut sudah stabil namun faktor lingkungan sangat mempengaruhi sifat fenotifik dari suatu varietas.

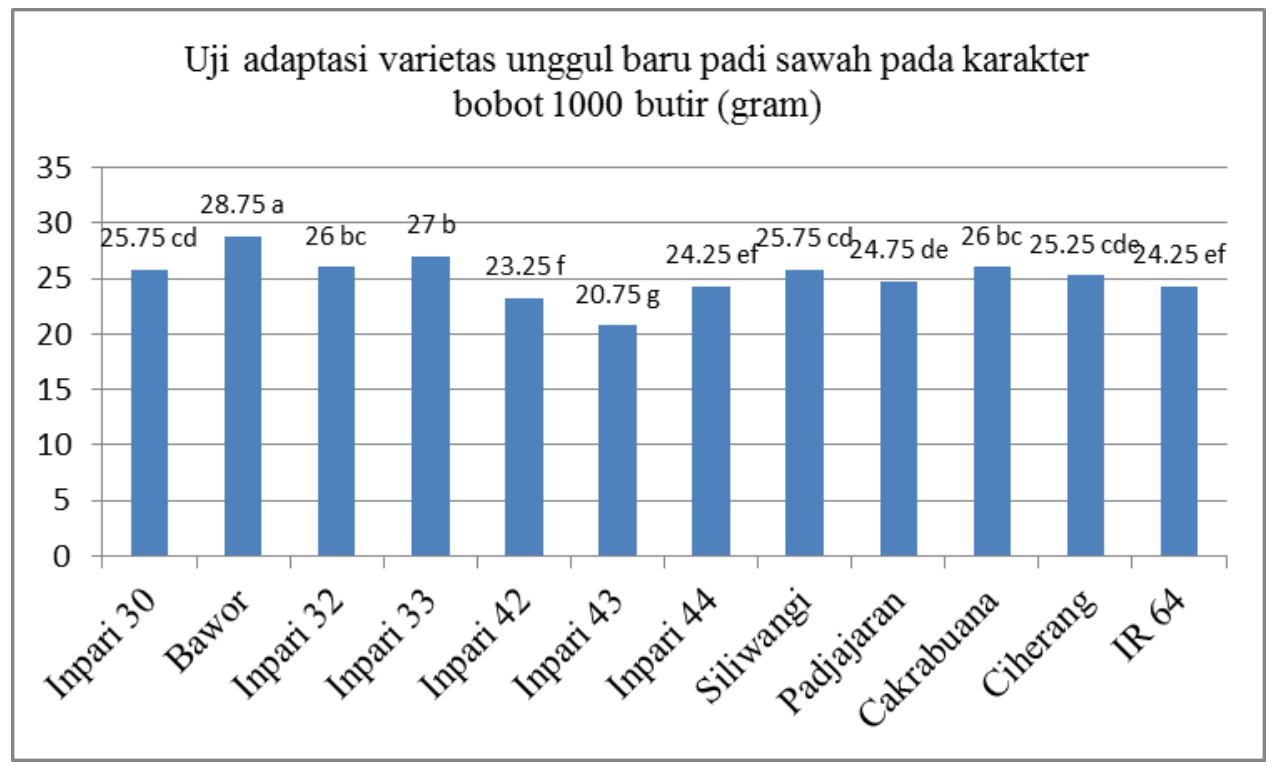

Gambar 5. Uji adaptasi varietas unggul baru padi sawah pada karakter bobot 1000 butir (Gram)

Hasil analisis statistik menunjukkan bahwa terdapat pengaruh nyata macam varietas terhadap keragaan hasil gabah kering panen dari dua belas varietas yang diteliti yang tertera pada Gambar 6. Uji adaptasi varietas unggul baru padi sawah pada karakter hasil gabah kering panen pada Gambar 6 menunjukkan bahwa varietas Inpari 44 menunjukkan adaptasi hasil yang paling tinggi yaitu 6.8 ton/ha jika dibandingkan dengan adaptasi hasil varietas yang lainnya. Hasil gabah berhubungan erat dengan komponen hasil seperti jumlah anakan, jumlah gabah isi per malai, persentase gabah isi dan bobot 1.000 butir. Tingginya perolehan hasil varietas Inpari 44 ditunjang oleh jumlah anakan yang lebih banyak dibanding varietas yang lainnya. Varietas yang menunjukkan adaptasi lebih tinggi dibandingkan dengan varietas pembanding Ciherang (6.1 ton/ha) pada karakter hasil adalah Bawor (6.55 ton/ha), Inpari 32 (6.15 ton/ha), Inpari 43 (6.5 ton/ha) dan Inpari 44 (6.8 ton/ha). Varietas-varietas ini dapat diadopsi petani untuk ditanam dilahannya sebagai alternatif rotasi varietas tanaman padi agar tidak selalu tanam Ciherang dan IR64 terus dan juga agar hasil produksi padinya tinggi. Berbeda halnya dengan varietas Padjajaran yang menunjukkan adaptasi paling 
P-ISSN 2580 - 7781

E-ISSN 2615 - 3238

rendah pada karakter hasil yaitu 4.05 ton/ha jika dibandingkan dengan adaptasi varietas yang lainnya. Hal ini dikarenakan varietas Padjajaran memiliki umur berbunga yang sangat genjah atau paling cepat dibandingkan dengan varietas yang lainnya dan bahkan dibandingkan dengan pertanaman padi milik petani di sekitar sehingga malainya banyak yang terserang hama burung. Walaupun segala upaya penanggulangan sudah dilakukan agar burung tidak mengganggu produktivitas varietas Padjajaran tersebut.

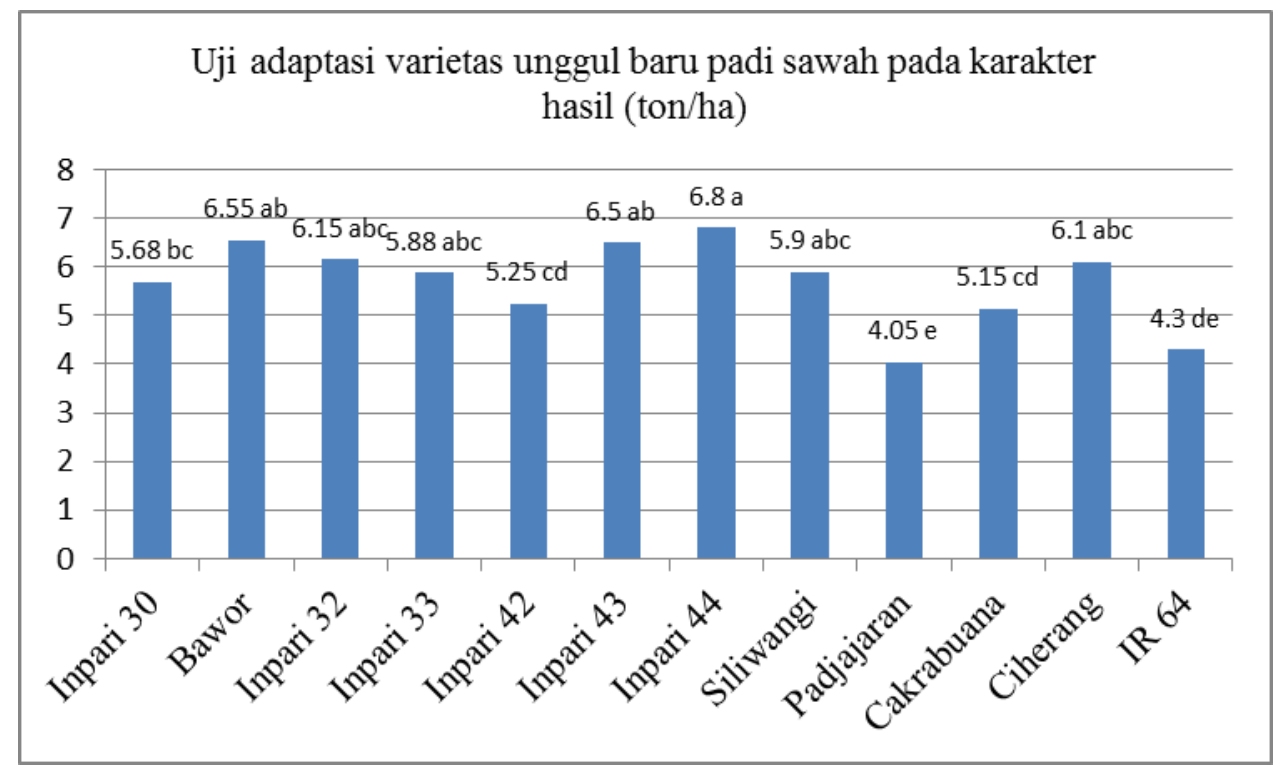

Gambar 6. Uji adaptasi varietas unggul baru padi sawah pada karakter hasil gabah kering panen (Ton/Ha)

\section{KESIMPULAN}

1. Terdapat perbedaan antar varietas yang diuji pada karakter hasil, jumlah anakan, umur berbunga 50\%, jumlah gabah hampa per malai dan seed set serta tidak menunjukkan perbedaan yang nyata pada karakter yang lainnya.

2. Inpari 44 (6.8 ton/ha), Bawor (6.55 ton/ha), Inpari 43 (6.5 ton/ha) dan Inpari 32 (6.15 ton/ha) menunjukkan adaptasi yang lebih tinggi dari varietas pembanding Ciherang (6.1 ton/ha) dan IR64 94.3 ton/ha) di Kecamatan Karangsambung, Kabupaten Kebumen. 
P-ISSN 2580 - 7781

E-ISSN 2615 - 3238

\section{UCAPAN TERIMA KASIH}

Penelitian ini terlaksana dengan anggaran dari Direktorat Riset dan Pengabdian Masyarakat Kementerian Riset dan Teknologi / Badan Riset dan Inovasi Nasional Tahun 2020 untuk katagori Penelitian Kompetitif Nasional Skema Penelitian Dosen Pemula.

\section{DAFTAR PUSTAKA}

Badan Pusat Statistik. 2017. Produksi, Luas panen dan Produktivitas Padi di Indonesia.

Badan Pusat Statistik Kabupaten Kebumen. 2017. Luas Panen dan Produksi Padi di Kabupaten Kebumen.

Balai Penelitian Tanaman Padi. 2011. Deskripsi Padi. Balai Penelitian Tanaman Padi. Sukamandi, Subang. Diakses pada 5 Desember 2020. http://etd.repository.ugm.ac.id/index.php?mod=download\&sub=Downloa $\mathrm{dFile} \&$ act $=$ view $\&$ typ $=\mathrm{html} \& \mathrm{id}=67872 \& \mathrm{ftyp}=$ potongan\&potongan $=\mathrm{S} 1-$ 2014-269807-bibliography.pdf.

Direktorat Perlindungan Tanaman Pangan. 2012. Laporan tahunan data luas serangan penyakit hawar daun bakteri tanaman padi. Diakses pada 1 Desember 2020. http://ditjentan.deptan.go.id.

Edi, Syafri. 2013. Keragaan Varietas Dan Galur Harapan Padi Gogo Pada Daerah Aliran Sungai Batang Asai Sarolangun Jambi. Program Studi Agroekoteknologi, Fakultas Pertanian Universitas Jambi. Volume 2 No. 3 Juli-September 2013.

Effendi, T.A. 2009. Jenis Arthopoda Predator Penghuni Tajuk dan Permukaan Tanah di Ekosistem tanaman Padi, M23, 1-7. Diakses pada 5 Desember 2020. http://www.pur-plsounsri. org/dokumen/1_septiana-anggraini_red 1.pdf.

Gardner, Franklin. P R B Pierce. RL Mitchel. 1991. Fisiologi Tumbuhan Budidaya. Terjemahan Herawati Susilo. Universitas Indonesia. Jakarta.

Guswara, A.2007. Peningkatan Hasil Tanaman Padi Melalui Pengembangan Padi Hibrida : Dalam Kumpulan RDTP/ROPP. Balai Besar Penelitian Tanaman Padi. Sukamandi.

Harjadi, S. 1993. Budidaya Tanaman Pangan Padi Hibrida. Gramedia Pustaka Utama. Jakarta.

Kadir, T., S. I. Hanarida. Utami,W. Koerniati, S. Ambarwati, A.D. Apriana, A. Sisharmini 2009. Evaluasi ketahanan populasi haploid ganda silangan IR64 dan Oryza rufipogon terhadap hawar daun bakteri pada stadia bibit. Bul. Plasma Nutfah 15:13-19. 
P-ISSN 2580 - 7781

E-ISSN 2615 - 3238

Kartohardjono. 2011. Penggunaan Musuh Alami Sebagai Komponen Pengendalian Hama Padi Berbasis Ekologi. Jurnal Pengembangan Inovasi Pertanian, 4(1): 29-46.

Lestari, A.P., H. Aswidinnoor, Suwarno. 2007. Uji daya hasil pendahuluan dan mutu beras 21 padi hibrida harapan. Bul. Agron. 35:1-7.

Mahmud, Y. dan Sulistyo S.P. 2014. Keragaman Agronomis Beberapa Varietas Unggul Baru Tanaman Padi (Oryza Sativa L.) Pada Model Pengelolaan Tanaman Terpadu. Jurnal Ilmiah Solusi Vol. 1 No.1 Januari - Maret 2014: 1-10.

Rugaya, A dan Dahyar. 2013. Identifikasi Biotipe Wereng Batang Coklat Nilaparvata lugens Stall. (Delphacidae, Homotera) Kaloni Kabupaten Takalar. Seminar Nasional Inovasi Teknologi Pertanian, 2013. Balai Proteksi Tanaman Pangan dan Hortikultura Sulawesi Selatan. Diakses pada 5 Desember 2020. http://sumsel.litbang.pertanian.go.id/ind/images/ pdf/seminar.nasional/ 23\%20rugaya.pdf.

Sutaryo, B dan Suprihatno, N. 1995. Evaluasi hasil dan komponen kombinasi hibrida padi turunan beberapa galur pemuliaan baru. Prosiding Simposium Pemuliaan Tanaman III. Balai Penelitian Tanaman Pangan. Sukamandi. 